\title{
STRATEGI PENGEMBANGAN NILAI-NILAI AGAMA DAN MORAL PADA ANAK USIA DINI DI TAMAN KANAK-KANAK DI JAWA BARAT
}

\author{
Edi Rohendi ${ }^{1}$ \\ Titing Rohayati ${ }^{2}$ \\ Jenuri $^{3}$
}

\begin{abstract}
ABSTRAK
Dari hasil observasi peneliti di lapangan terhadap kegiatan pelaksanaan tempat Praktek Pengalaman Lapangan (PPL) mahasiswa PG PAUD UPI Kampus Cibiru, hasil diskusi dengan guru-guru TK hampir tidak ditemukan pelaksanaan pengembangan nilai-nilai agama dan moral secara terintegrasi yang terprogram dalam perencanaan pembelajaran Rencana Kegiatan Harian (RKH) terutama pada kegiatan inti. Oleh karena itu penelitian ini dilakukan dengan tujuan mengkaji strategi pengembangan agama dan moral di taman kanak-kanak. Hasil penelitian menunjukkan bahwa implementasi strategi pengembangan nilai-nilai agama dan moral melalui kegiatan rutinitas dilakukan oleh hampir seluruh guru TK di Jawa Barat, sejumlah 90,25\% guru mengetahui, memahami dan mengimplementasikannya pada pelaksanaan kegiatan rutiniitas, dan dikategorikan baik. Implementasi strategi pengembangan nilai-nilai agama dan moral melalui kegiatan terintegrasi sejumlah $48,3 \%$ guru di Jawa Barat, mengimplementasikan pada kegiatan terintegrasi melalui kegiatan inti sehingga dikategorikan kurang baik. Implementasi strategi pengembangann nilai-nilai agama dan moral melalui kegiatan khusus, guru telah memahami dan melaksanakan kegiatan khusus sejumlah 86\%, sehingga dikategorikan baik.
\end{abstract}

Kata Kunci : Strategi Pengembangan Nilai-Nilai Agama dan Moral, Anak Usia Dini, Taman Kanak-Kanak

\section{A. PENDAHULUAN}

Dari hasil observasi peneliti dilapangan terhadap kegiatan pelaksanaan tempat Praktek Pengalaman Lapangan (PPL) mahasiswa PG PAUD UPI kampus Cibiru, hasil diskusi dengan guru-guru TK hampir tidak ditemukan pelaksanaan pengembangan nilai-nilai agama dan moral secara terintegrasi yang terprogram dalam perencanaan pembelajaran Rencana Kegiatan Harian (RKH) terutama pada kegiatan inti. Sebagian besar guru TK melaksanakan pengembangan nilai-nilai agama dan moral hanya pada kegiatan rutinitas saja seperti membaca doa mau belajar dan selesai belajar, mengucapkan salam, berdoa di kegiatan makan, serta kegiatan khusus yang dilaksanakan diluar perencanaan pemebelajaran (RKH). Hanya sedikit RKH yang mengintegrasikan pengembangan nilai-nilai agama dengan disisipkan dengan pengembangan dasar lainnya seperti pengembangan bahasa,

\footnotetext{
${ }^{1}$ Dosen UPI Kampus Cibiru

${ }^{2}$ Dosen UPI Kampus Cibiru

${ }^{3}$ Dosen UPI Kampus Cibiru
} 
kognitif, dan fisik motorik. Pengembangan nilai-nilai agama dan moral semestinya terprogram secara terencana dalam $\mathrm{RKH}$ dan dilakukan secara terintegrasi pada kegiatan inti. Tujuan penelitian ini adalah untuk mengetahui bentuk pengembangan nilai-nilai agama dan moral melalui kegiatan rutinitas, terintegrasi dan kegiatan khusus. Penekanan pada penelitian ini dititikberatkan pada strategi pengembangan kegiatan terintegrasi, artinya pengembangan nilai-nilai agama dan moral diintegrasikan dengan pengembangan kemampuan dasar lainnya (bahasa, kognitif, dan fisik-motorik).

\section{B. METODE PENELITIAN}

Penelitian ini dilaksanakan selama 8 bulan. Penelitian ini dilakukan di lembaga Taman kanak-kanak di 10 Kabupaten / Kota di Jawa Barat diantaranya : Kota Bandung, Kabupaten Bandung, Kota Cimahi, Kabupaten Bandung Barat, Kabupaten Sumedang, Kabupaten Majalengka, Kabupaten Kuningan, Kabupaten Garut, Kabupaten Tasikmalaya, Kota Tasikmalaya, dengan mengambil sampel dua Taman kanak-kanak di setiap Kabupaten/Kota di Jawa Barat secara acak

Penelitian ini menggunakan pendekatan kualitatif dengan metode deskriptif analitik. Tehnik pengumpulan data yang menjadi instrument adalah angket, wawancara, observasi dan studi dokumentasi. Penelitian ini ditunjukkan untuk mengetahui bagaimana implementasi strategi pengembangan nilai-nilai agama dan moral melalui strategi kegiatan rutinitas, strategi kegiatan terintegrasi, dan strategi kegiatan khusus.

Subjek di dalam penelitian pengembangan nilai-nilai agama dan moral di TK ini adalah guru di sepuluh kabupaten / kota di Jawa Barat dengan masing-masing sampel satu guru tiap satu sekolah. Instrumen pengumpul data menggunakan metode triangulasi yakni: observasi, wawancara, angket dan studi dokumentasi Dalam menganalisis data tehnik yang digunakan oleh peneliti adalah deskriptif analitis yang terdiri dari tiga tahapan yaitu pengumpulan data sekaligus mereduksi, penyajian data, dan penarikan kesimpulan

\section{HASIL PENELITIAN}

Pendekatan yang dilakukan pada penelitian ini adalah penelitian deskriptif analitis Dimana data diperoleh melalui pengamatan, angket, dan wawancara. Data hasil penelitian melalui ketiga alat tersebut, bersifat kualitatif dan kuantitatif, kemudian peneliti kumpulkan dan analisis. Data kualitatif dianalisis dengan cara mendeskripsikan hasil penelitian pada metode triangulasi. Data kuantitatif dianalisis dengan program Ms. Excel Word dan kemudian di jelaskan secara deskriptif hasil dari analisis tersebut.

Pertama, analisis wawancara yang telah dikemukakan oleh 20 guru TK di 10 Kota dan Kabupaten di Jawa Barat. Hasil instrumen wawancara merupakan analisis deskriptif berdasarkan jawaban guru atas pertanyaan-pertanyaan yang disampaikan dalam kuesioner pada pedoman wawancara di TK masing-masing tempat penelitian. Adapun hasilnya disajikan sebagai berikut:

1. Kegiatan strategi pengembangan nilai-nilai agama dan moral melalui kegiatan rutinitas, kegiatan yang dilakukan oleh guru didalam strategi pengembangan 
moral agama melalui kegiatan rutinitas bervariasi. Namun secara keseluruhan kegiatan berdoa sebelum dan sesudah belajar merupakan kegiatan yang rutin dilakukan oleh seluruh sekolah

2. Kegiatan Pengembangan Nilai-nilai Agama dan Moral melalui kegiatan terintegrasi, Maka banyak sekali guru yang belum paham tentang apa strategi pengembangan nilai-nilai agama dan moral melalui kegiatan terintegrasi. Kegiatan yang dilakukan guru diantaranya: memberi dan membalas salam, berdoa sebelum dan sesusah belajar, berdoa sebelum dan sesudah makan, sikap sopan santun dan mengucapkan terimakasih, nyanyian lagu islami. Adapun kegiatan pengembangan nilai-nilai agama dan moral dengan cara menyisipkan dalam kegiatan inti/ tematik. Seperti : menyisipkan nilai agama dan moral dalam materi kegiatan sesuai tema, misal menerangkan tentang binatang ciptaan Tuhan YME, dan bagaimana kita bersyukur dengan segala karunia yang telah Allah berikan, baru dilakukan oleh $25 \%$ guru.

3. Kegiatan Pengembangan Nilai-nilai Agama dan Moral melalui kegiatan khusus, keseluruhan guru sudah tepat didalam strategi pengembangan nilai-nilai agama dan moral melalui kegiatan khusus, misalnya: Mengahafal surat-surat pendek, menghafal doa sehari-hari, membaca iqro, menulis huruf hijaiyah, praktek wudlu, praktek sholat dan manasik haji, praktek sedekah, dan berkunjung ke tempat ibadah.

4. pelaksanaan strategi pengembangan nilai-nilai agama dan moral melalui kegiatan terintegrasi, dapat disimpulkan hanya $35 \%$ guru yang memahami bagaimana pelaksanaan strategi pengembangan nilai-nilai agama dan moral melalui kegiatan terintegrasi. Bentuk kegiatan pengembangan yang diselipkan pada tema kegiatan pengembangan sehari-hari, misalnya pengembangan pada tema panca indera, binatang ternak, tumbuh-tumbuhan, dll.

5. Metode Pengembangan nilai-nilai agama dan moral secara terintegrasi di kelas, Keseluruhan guru telah menggunakan varian metode didalam pengembangan nilai-nilai agama dan moral ini. melalui metode: bercerita, bernyanyi, sosio drama, karya wisata, bercakap-cakap, proyek, praktek langsung

6. Media yang digunakan pada pengembangan nilai-nilai agama dan moral pada kegiatan terintegrasi di kelas, seluruhnya menggunakan media didalam strategi pengembangan nilai-nilai agama dan moral melalui kegiatan terintegrasi, namun yang paling banyak digunakan media didalam pengembangan tersebut adalah media gambar.

7. Kegiatan pengembangan nilai-nilai agama dan moral terencana dan terprogram, hasil wawancara $75 \%$ guru mengemukakan telah membuat perencanaan kegiatan pengembangan berupa dokumen RKH secara terencana dan terprogram.

8. Pengembangan nilai-nilai keimanan secara terintegrasi dalam kegiatan inti, beberapa guru sudah tepat mengembangkan nilai-nilai keimanan di kelas, misalnya bercerita alam semesta dan isinya, penanaman rukun iman dan rukun islam. Penanaman nabi Muhammad SAW, pemberian contoh perbuatan baik dan buruk, mengaitkan tema kegiatan dengan kekuasaan Allah SWT, melalui kegiatan bernyanyi yang bernuansa keagamaan. 
9. Pengembangan sikap (moral) secara terintegrasi dalam kegiatan inti, Sebagian guru $(60 \%)$ disetiap kelas di masing-masing sekolah mengembangkan sikap disiplin, sopan santun, sikap duduk yang baik, hormat kepada guru, menjaga kebersihan, tanggung jawab, mengerjakan tugas sampai selesai, menyimpan mainan ketempat semula, tidak mengganggu teman, membuang sampah pada tempatnya, sikap hormat kepada teman dan guru.

10. Pengembangan nilai-nilai agama dan moral terprogram dan konsisten dilaksanakan secara terintegrasi, hasil wawancara sebagian besar guru belum membuat perencanaan pengembangan nilai-nilai agama dan moral secara terprogram dan konsisten.

Alat pengumpul data yang kedua adalah angket. Hasil dari analisis dalam lembaran angket yang telah dikemukakan oleh 20 guru TK di 10 Kota dan Kabupaten di Jawa Barat dapat disimpulkan pengembangan nilai-nilai agama dan moral yang dikembangkan oleh guru melalui kegiatan rutinitas, seperti tabel 1

Tabel 1

Hasil angket pengembangan nilai-nilai agama dan moral melalui kegiatan rutinitas

\begin{tabular}{|c|c|c|c|c|}
\hline No & Item pernyataan & Skor & Persen & Kategori \\
\hline 1 & $\begin{array}{l}\text { Anda mengetahui strategi pengembangan nilai- } \\
\text { nilai agama dan moral di TK }\end{array}$ & 20 & 100 & BAIK \\
\hline 2 & $\begin{array}{l}\text { Anda memahami strategi pengembangan nilai-nilai } \\
\text { agama dan moral di TK }\end{array}$ & 16 & 80 & BAIK \\
\hline 3 & $\begin{array}{l}\text { Anda mengetahui strategi pengembangan kegiatan } \\
\text { rutinitas dalam pengembangan nilai-nilai agama } \\
\text { dan moral di TK }\end{array}$ & 17 & 85 & BAIK \\
\hline 4 & $\begin{array}{l}\text { Dalam kegiatan rutinitas anda senantiasa } \\
\text { mengembangkan pembiasaan memberi salam }\end{array}$ & 20 & 100 & BAIK \\
\hline 5 & $\begin{array}{l}\text { Dalam kegiatan rutinitas anda mengembangkan } \\
\text { pembiasaan dalam menunjukan sikap berdoa }\end{array}$ & 20 & 100 & BAIK \\
\hline 6 & $\begin{array}{l}\text { Dalam kegiatan rutinitas anda mengembangakan } \\
\text { pembiasaan berdoa mau belajar }\end{array}$ & 20 & 100 & BAIK \\
\hline 7 & $\begin{array}{l}\text { Dalam kegiatan rutinitas anda mengembangkan } \\
\text { pembiasaan berdoa sebelum dan sesudah } \\
\text { mengerjakan sesuatu }\end{array}$ & 20 & 100 & BAIK \\
\hline 8 & $\begin{array}{l}\text { Dalam kegiatan rutinitas anda mengembangkan } \\
\text { pembiasaan berdoa sebelum dan sesudah makan }\end{array}$ & 20 & 100 & BAIK \\
\hline 9 & $\begin{array}{l}\text { Dalam kegiatan rutinitas anda mengembangkan } \\
\text { pembiasaan berdoa mau pulang }\end{array}$ & 20 & 100 & BAIK \\
\hline 10 & $\begin{array}{l}\text { Dalam kegiatan rutinitas anda mengembangkan } \\
\text { pembiasaan sikap duduk yang baik }\end{array}$ & 19 & 95 & BAIK \\
\hline 11 & $\begin{array}{l}\text { Dalam kegiatan rutinitas anda mengembangkan } \\
\text { pembiasaan sikap hormat kepada guru }\end{array}$ & 19 & 95 & BAIK \\
\hline 12 & $\begin{array}{l}\text { Dalam kegiatan rutinitas anda mengembangkan } \\
\text { pembiasaan sikap tanggung jawab terhadap tugas } \\
\text { yang diberikan }\end{array}$ & 19 & 95 & BAIK \\
\hline
\end{tabular}




\begin{tabular}{|c|c|c|c|c|}
\hline 13 & $\begin{array}{l}\text { Dalam kegiatan rutinitas anda mengembangkan } \\
\text { pembiasaan sikap menjaga kebersihan lingkungan }\end{array}$ & 20 & 100 & BAIK \\
\hline 14 & $\begin{array}{l}\text { Dalam kegiatan rutinitas anda mengembangkan } \\
\text { pembiasaan sikap mengurus diri sendiri,seperti } \\
\text { membersihkan diri,berpakaian sendiri, makan } \\
\text { sendiri dan memelihara milik sendiri }\end{array}$ & 17 & 85 & BAIK \\
\hline 15 & $\begin{array}{l}\text { Dalam kegiatan rutinitas anda mengembangkan } \\
\text { pembiasaan sikap disiplin,seperti menyimpan } \\
\text { mainan ke tempat semula }\end{array}$ & 16 & 80 & BAIK \\
\hline 16 & $\begin{array}{l}\text { Dalam kegiatan rutinitas anda mengembangkan } \\
\text { sikap sopan santun,seperti mengucapkan } \\
\text { terimakasih dengan baik,meminta tolong dengan } \\
\text { baik. }\end{array}$ & 18 & 90 & BAIK \\
\hline 17 & $\begin{array}{l}\text { Dalam kegiatan rutinitas anda mengembangkan } \\
\text { pembiasaan berlatih untuk selalu tertib dan patuh } \\
\text { pada peraturan, seperti berpakain seragam, masuk } \\
\text { sekolah tepat waktu }\end{array}$ & 19 & 95 & BAIK \\
\hline 18 & $\begin{array}{l}\text { Dalam kegiatan rutinitas anda mengembangkan } \\
\text { secara terprogram dalam RKM (Rencana Kegiatan } \\
\text { Mingguan) }\end{array}$ & 14 & 70 & CUKUP \\
\hline 19 & $\begin{array}{l}\text { Dalam kegiatan rutinitas anda mengembangkan } \\
\text { secara terprogram dalam RKH (Rencana Kegiatan } \\
\text { Harian) }\end{array}$ & 14 & 70 & CUKUP \\
\hline \multirow[t]{3}{*}{20} & $\begin{array}{l}\text { Dalam kegiatan rutinitas anda biasa } \\
\text { mengembangkan pembiasaan yang terprogram dan } \\
\text { konsisten dengan aktifitas belajar anak }\end{array}$ & 14 & 70 & CUKUP \\
\hline & JUMLAH & 361 & 1805 & \\
\hline & RATA-RATA & 18.05 & 90.25 & \\
\hline
\end{tabular}

Rekapitulasi hasil jawaban responden tentang pengembangan nilai-nilai agama dan moral melalui kegiatan rutinitas adalah sebagai berikut:

$$
\begin{aligned}
& \text { Rata-rata skor }=\frac{\text { total skor }}{\text { jumlah } \text { item }} \\
& \begin{aligned}
\text { Rata-rata skor } & =\frac{361}{20} \\
& =18.05
\end{aligned}
\end{aligned}
$$

Selanjutnya ditentukan dalam bentuk presentasi dengan penghitungan sebagai berikut:

$$
\begin{aligned}
& \text { Presentasi skor }=\frac{\text { skor } \text { rata }- \text { rata }}{\text { skor ideal }} \times 100 \% \\
& \begin{aligned}
\text { Presentasi skor } & =\frac{1805}{20} \\
& =90.25 \%
\end{aligned}
\end{aligned}
$$


Dari perhitungan diperoleh presentasi skor nilai 90,25\% sehingga apabila dimasukan kedalam kategori presentase menurut Arikunto (1998:246), yaitu:

Tabel 2

Kategori Presentase

\begin{tabular}{|l|l|}
\hline Baik & $76 \%-100 \%$ \\
\hline Cukup & $56 \%-75 \%$ \\
\hline Kurang Baik & $40 \%-55 \%$ \\
\hline Tidak Baik & Kurang dari $40 \%$ \\
\hline
\end{tabular}

Maka strategi pengembangan nilai-nilai agama dan moral melalui kegiatan rutinitas di Taman Kanak-kanak di Jawa Barat memiliki kategori yang baik yaitu sebesar $90,25 \%$.

Hasil dari analisis dalam lembaran angket yang telah dikemukakan oleh 20 guru TK di 10 Kota dan Kabupaten di Jawa Barat dapat disimpulkan pengembangan nilai-nilai agama dan moral yang dikembangkan oleh guru melalui kegiatan terintegrasi, dapat dilihat pada tabel 3 dibawah ini

Table 3

Hasil angket pengembangan nilai-nilai agama dan moral melalui kegiatan terintegrasi

\begin{tabular}{|l|l|l|l|l|}
\hline No & Item pernyataan & Skor & Persen & Kategori \\
\hline 1 & $\begin{array}{l}\text { Dalam mengembangkan nilai-nilai agama dan } \\
\text { moral anda mengetahui strategi pembelajaran } \\
\text { secara terintegrasi }\end{array}$ & 25 & TIDAK BAIK \\
\hline 2 & $\begin{array}{l}\text { Dalam mengembangkan nilai-nilai agama dan } \\
\text { moral anda memahami strategi pembelajaran } \\
\text { secara terintegrasi }\end{array}$ & 4 & 20 & TIDAK BAIK \\
\hline 3 & $\begin{array}{l}\text { Dalam mengembangkan nilai-nilai agama dan } \\
\text { moral anda melaksanakan strategi pembelajaran } \\
\text { secara terintegrasi }\end{array}$ & 8 & 40 & KURANGBAIK \\
\hline 4 & $\begin{array}{l}\text { Dalam kegiatan terintegrasi anda } \\
\text { mengembangkan secara terprogram dalam RKH } \\
\text { (Rencana Kegiatan harian) }\end{array}$ & 8 & 40 & KURANGBAIK \\
\hline 5 & $\begin{array}{l}\text { Dalam kegiatan terintegrasi anda menggunakan } \\
\text { metode bernyanyi }\end{array}$ & 14 & 70 & BAIK \\
\hline 6 & $\begin{array}{l}\text { Dalam kegiatan terintegrasi anda menggunakan } \\
\text { metode bercerita }\end{array}$ & 15 & 75 & BAIK \\
\hline 7 & $\begin{array}{l}\text { Dalam kegiatan terintegrasi anda menggunakan } \\
\text { metode proyek }\end{array}$ & 8 & 40 & TIDAK BAIK \\
\hline 8 & $\begin{array}{l}\text { Dalam kegiatan terintegrasi anda menggunakan } \\
\text { metode sosio drama }\end{array}$ & 4 & 20 & TIDAK BAIK \\
\hline 9 & $\begin{array}{l}\text { Dalam kegiatan terintegrasi anda menggunakan } \\
\text { metode karya wisata }\end{array}$ & 3 & 15 & TIDAK BAIK \\
\hline 10 & $\begin{array}{l}\text { Dalam kegiatan terintegrasi anda menggunakan } \\
\text { metode bercerita }\end{array}$ & 15 & 75 & BAIK \\
\hline 11 & Dalam kegiatan terintegrasi anda menggunakan & 9 & 45 & TIDAK BAIK \\
\hline
\end{tabular}




\begin{tabular}{|l|l|l|l|l|}
\hline & metode bercakap-cakap & & & \\
\hline 12 & $\begin{array}{l}\text { Dalam pengembangan pengembangan nilai-nilai } \\
\text { agama dan moral dilaksanakan pada kegiatan } \\
\text { inti secara terintegrasi }\end{array}$ & $\begin{array}{l}\text { KURANG } \\
\text { BAIK }\end{array}$ \\
\hline 13 & $\begin{array}{l}\text { Dalam pengembangan nilai agama dan moral } \\
\text { dilaksanakan melalui kegiatan bernyanyi dengan } \\
\text { lagu-lagu keagamaan }\end{array}$ & $\begin{array}{l}\text { Dalam pengembangan nilai-nilai agama } \\
\text { dilaksanakan secara terintegrasi dengan } \\
\text { pengembangan kemampuan dasar lainnya } \\
\text { (bahasa, fisik, kognitif,sosial emosional) }\end{array}$ & 70 & BAIK \\
\hline 15 & $\begin{array}{l}\text { Dalam kegiatan terintegrasi anda biasa } \\
\text { mengembangkan pembiasaan yang terprogram } \\
\text { dan konsisten dengan aktifitas belajar anak }\end{array}$ & 11 & 55 & $\begin{array}{l}\text { KURANG } \\
\text { BAIK }\end{array}$ \\
\hline & JUMLAH & 145 & 725 & \\
\hline & RATA-RATA & 9,67 & 48,3 & \\
\hline
\end{tabular}

Rekapitulasi hasil jawaban responden tentang pengembangan nilai-nilai agama dan moral melalui kegiatan terintegrasi adalah sebagai berikut:

$$
\begin{aligned}
\text { Rata-rata skor } & =\frac{\text { total skor }}{\text { jumlah } \text { item }} \\
\text { Rata-rata skor } & =\frac{151}{15} \\
& =9,67
\end{aligned}
$$

Selanjutnya ditentukan dalam bentuk presentasi dengan penghitungan sebagai berikut:

$$
\begin{gathered}
\text { Presentasi skor }=\frac{\text { skor rata-rata }}{\text { skor ideal }} \times 100 \% \\
\begin{aligned}
\text { Presentasi skor } & =\frac{725}{15} \\
& =48,3 \%
\end{aligned}
\end{gathered}
$$

Dari perhitungan diperoleh presentasi skor nilai 48,3\%, sehingga apabila dimasukan kedalam kategori presentase menurut Arikunto (1998:246), yaitu:

\section{Tabel 4}

Kategori Presentase

\begin{tabular}{|l|l|}
\hline Baik & $76 \%-100 \%$ \\
\hline Cukup & $56 \%-75 \%$ \\
\hline Kurang Baik & $40 \%-55 \%$ \\
\hline Tidak Baik & Kurang dari $40 \%$ \\
\hline
\end{tabular}

Maka strategi pengembangan nilai-nilai agama dan moral melalui kegiatan terintegrasi di Taman Kanak-kanak di Jawa Barat memiliki kategori kurang baik.

Hasil dari analisis dalam lembaran angket yang telah dikemukakan oleh 20 guru TK di 10 Kota dan Kabupaten di Jawa Barat dapat disimpulkan pengembangan nilai-nilai agama dan moral yang dikembangkan oleh guru melalui kegiatan terintegrasi, dapat dilihat pada table 5 
Tabel 5

Hasil angket pengembangan nilai-nilai agama dan moral melalui kegiatan khusus

\begin{tabular}{|c|c|c|c|c|}
\hline No & Item pernyataan & Skor & Persen & Kategori \\
\hline 1 & $\begin{array}{l}\text { Dalam mengembangkan nilai-nilai agama dan } \\
\text { moral anda mengetahui strategi pembelajaran } \\
\text { secara khusus }\end{array}$ & 17 & 85 & BAIK \\
\hline 2 & $\begin{array}{l}\text { Dalam mengembangkan nilai-nilai agama dan } \\
\text { moral anda memahami strategi pembelajaran } \\
\text { secara khusus }\end{array}$ & 16 & 80 & BAIK \\
\hline 3 & $\begin{array}{l}\text { Dalam mengembangkan nilai-nilai agama dan } \\
\text { moral anda melaksanakan strategi } \\
\text { pembelajaran secara khusus }\end{array}$ & 19 & 95 & BAIK \\
\hline 4 & $\begin{array}{l}\text { Dalam mengembangkan nilai-nilai agama dan } \\
\text { moral, praktek hafalan surat pendek } \\
\text { dilaksanakan melalui kegiatan khusus }\end{array}$ & 17 & 85 & BAIK \\
\hline 5 & $\begin{array}{l}\text { Dalam mengembangkan nilai-nilai agama dan } \\
\text { moral, praktek sholat dilaksanakan melalui } \\
\text { kegiatan khusus }\end{array}$ & 18 & 90 & BAIK \\
\hline 6 & $\begin{array}{l}\text { Dalam mengembangkan nilai-nilai agama dan } \\
\text { moral, praktek wudlu dan tayamum } \\
\text { dilaksanakan melalui kegiatan khusus }\end{array}$ & 18 & 90 & BAIK \\
\hline 7 & $\begin{array}{l}\text { Dalam mengembangkan nilai-nilai agama dan } \\
\text { moral, praktek mengenal dan menulis huruf } \\
\text { hijaiyah dilaksanakan melalui kegiatan khusus }\end{array}$ & 17 & 85 & BAIK \\
\hline 8 & $\begin{array}{l}\text { Dalam mengembangkan nilai-nilai agama dan } \\
\text { moral, praktek manasik haji dilaksanakan } \\
\text { melalui kegiatan khusus }\end{array}$ & 19 & 95 & BAIK \\
\hline 9 & $\begin{array}{l}\text { Dalam mengembangkan nilai-nilai agama dan } \\
\text { moral, praktek berkunjung ke tempat ibadah } \\
\text { dilaksanakan melalui kegiatan khusus }\end{array}$ & 18 & 90 & BAIK \\
\hline \multirow[t]{3}{*}{10} & $\begin{array}{l}\text { Dalam kegiatan khusus anda biasa } \\
\text { mengembangkan pembiasaan yang } \\
\text { terprogram dan konsisten dengan aktifitas } \\
\text { belajar anak }\end{array}$ & 19 & 95 & BAIK \\
\hline & JUMLAH & 178 & 860 & \\
\hline & RATA-RATA & 17.8 & 86 & \\
\hline
\end{tabular}

Rekapitulasi hasil jawaban responden tentang pengembangan nilai-nilai agama dan moral melalui kegiatan khusus adalah sebagai berikut:

$$
\begin{aligned}
\text { Rata-rata skor } & =\frac{\text { total } \text { skor }}{\text { jumlah } \text { item }} \\
\text { Rata-rata skor } & =\frac{178}{10} \\
& =17.8
\end{aligned}
$$
berikut:

Selanjutnya ditentukan dalam bentuk presentasi dengan penghitungan sebagai

Presentasi skor $=\frac{\text { skor } \text { rata }- \text { rata }}{\text { skor } \text { ideal }} \times 100 \%$ 


$$
\begin{aligned}
\text { Presentasi skor } & =\frac{860}{10} \\
& =86 \%
\end{aligned}
$$

Dari perhitungan diperoleh presentasi skor nilai $86 \%$, sehingga apabila dimasukan kedalam kategori presentase menurut Arikunto (1998:246), yaitu:

Tabel 6

Kategori Presentase

\begin{tabular}{|l|l|}
\hline Baik & $76 \%-100 \%$ \\
\hline Cukup & $56 \%-75 \%$ \\
\hline Kurang Baik & $40 \%-55 \%$ \\
\hline Tidak Baik & Kurang dari $40 \%$ \\
\hline
\end{tabular}

Maka strategi pengembangan nilai-nilai agama dan moral melalui kegiatan khususs di Taman Kanak-kanak di Jawa Barat memiliki kategori baik.

Instrumen ketiga yang dijadikan sebagai alat dalam peneltian strategi pengembangan nilai-nilai agama dan moral di TK adalah observasi.Bentuk kegiatan observasi yang dilakukan oleh peneliti adalah dengan mengamati secara pasif tanpa ada tindakan partisipatif dari peneliti . Adapun hasil analisis lembar observasi dapat dilihat pada table 7 seperti tabel dibawah ini:

\begin{tabular}{|c|c|c|c|c|}
\hline $\mathrm{NO}$ & NAMA KEGIATAN & ADA & TIDAK ADA & KET \\
\hline 1 & $\begin{array}{l}\text { Dalam kegiatan pembelajaran guru } \\
\text { membuat RKH }\end{array}$ & 19 & 1 & \\
\hline Ket & \multicolumn{4}{|c|}{$\begin{array}{l}\text { Satu sekolah TK Sejahtera ketika pelaksanaan penelitian dilakukan, guru } \\
\text { menyampaikan belum mempersiapkan RKH karena masih menunggu dari gugus. } \\
\text { Dimana untuk satu gugus di wilayah tersebut program Rencana Kegiatan } \\
\text { Mingguan dan Rencana Kegiatan Harian akan di samakan/diseragamkan. }\end{array}$} \\
\hline 2 & $\begin{array}{l}\text { Pengembangan nilai-nilai agama dan moral } \\
\text { tercantum dalam RKH }\end{array}$ & 18 & 2 & \\
\hline Ket & \multicolumn{4}{|c|}{$\begin{array}{l}\text { Seluruhnya mencantumkan pengembangan nilai-nilai agama dan moral, hanya } \\
\text { dua TK saja yang tidak, yaitu TK Ade Irma Suryani dan TK Harapan Ibu }\end{array}$} \\
\hline 3 & $\begin{array}{l}\text { Pengembangan nilai - nilia agama dan } \\
\text { moral dilaksanakan dalam kegiatan rutinitas }\end{array}$ & 20 & 0 & \\
\hline Ket & \multicolumn{4}{|c|}{$\begin{array}{l}\text { Seluruh guru melakukan pengembangan nilai-nilai agama dan moral melalui } \\
\text { kegiatan rutinitas, walaupun yang dua TK diatas tidak mencantumkan tapi } \\
\text { dilaksanakan, seperti mengucapkan salam dan berdoa ketika mulai dan selesai } \\
\text { belajar }\end{array}$} \\
\hline 4 & $\begin{array}{l}\text { Pengembangan nilai -nilai agama dan moral } \\
\text { dilaksanakan dalam kegiatan terintegrasi }\end{array}$ & 3 & 17 & \\
\hline Ket & \multicolumn{4}{|c|}{$\begin{array}{l}\text { Hanya tiga sekolah yang melakukan kegiatan Pengembangan nilai -nilai agama } \\
\text { dan moral dilaksanakan dalam kegiatan terintegrasi, yakni TK Sekar Pertiwi, TK } \\
\text { Asih Putera, dan TK Aisyiyah. Selebihnya pada saat kegiatan inti hanya fokus } \\
\text { kepada tiga pengembangan dasar yakni fisik, bahasa dan kognitif. }\end{array}$} \\
\hline 5 & $\begin{array}{l}\text { Pengembangan nilai -nilai agama dan } \\
\text { moral dilaksanakan dalam kegiatan } \\
\text { khusus }\end{array}$ & 20 & 0 & \\
\hline
\end{tabular}

Tabel 5 Hasil analisis observasi pengembangan nilai-nilai agama dan morla di TK 


\begin{tabular}{|c|c|c|c|c|}
\hline Ket & \multicolumn{4}{|c|}{$\begin{array}{l}\text { Seluruh guru mengembangkan kegiatan khusus pada kegiatan pengembangan } \\
\text { nilai-nilai agama dan moral. Bentuk kegiatan dan waktu nya bervariasi tergantung } \\
\text { dari kebijakan sekolah masing-masing guru di tempat }\end{array}$} \\
\hline 6 & $\begin{array}{l}\text { Guru menggunakan metode dalam } \\
\text { mengembangkan nilai-nilai agama dan } \\
\text { moral }\end{array}$ & 20 & 0 & \\
\hline Ket & \multicolumn{4}{|c|}{$\begin{array}{l}\text { Seluruh guru menggunakan metode yang bervariatif didalam mengembangkan } \\
\text { nilai-nilai agama dan moral di kelas. Misalnya metode bercerita, bernyanyi, dan } \\
\text { bercakap-cakap ataupun praktek langsung. }\end{array}$} \\
\hline 7 & $\begin{array}{l}\text { Guru menggunakan media dalam } \\
\text { mengembangkan nilai-nilai agama dan } \\
\text { moral }\end{array}$ & 20 & 0 & \\
\hline Ket & \multicolumn{4}{|c|}{$\begin{array}{l}\text { Seluruh guru menggunakan media didalam pengembangan nilai-nilai agama dan } \\
\text { moral, misalnya media buku cerita bergambar dan boneka }\end{array}$} \\
\hline 8 & Guru mengembangkan nilai-nilai keimanan & 2 & 18 & \\
\hline Ket & \multicolumn{4}{|c|}{$\begin{array}{l}\text { Hanya dua guru yang melakukan pengembangan nilai-nilai keimanan pada saat } \\
\text { peneliti melakukan kegiatan penelitian, yaitu di TK Sekar Pertiwi dan TK Asih } \\
\text { Putera. Bentuk kegiatannya misalnya mengenalkan segala mahluk hidup ciptaan- } \\
\text { ciptaan Tuhan YME dan bagaimana kita mensyukuri dengan merawat dan } \\
\text { menjaganya. Selebihnya tidak nampak }\end{array}$} \\
\hline 9 & Guru mengembangkan nilai-nilai sikap & 20 & & \\
\hline Ket & \multicolumn{4}{|c|}{$\begin{array}{l}\text { Seluruh guru mengembangkan nilai-nilai sikap seperti sikap hormat, saling } \\
\text { menolong, berpakaian rapi, menjaga kebersihan lingkungan, dll. }\end{array}$} \\
\hline 10 & $\begin{array}{l}\text { Guru memahami strategi pengembangan } \\
\text { nilai-nilai agama dan moral }\end{array}$ & 20 & 0 & \\
\hline & \multicolumn{4}{|c|}{$\begin{array}{l}\text { Guru terlihat memahami strategi pengembangan nilai-nilai agama dan moral hanya } \\
\text { sebatas pada kegiatan ritinitas pembiasaan dan bahkan ada yang menyebutkan } \\
\text { kegiatan khusus merupakan kegiatan pengembangan yang terencana masuk ke } \\
\text { dalam dokumen Rencana Kegiatan Harian (RKH), tetapi bentuk kegiatan } \\
\text { terintegrasi didalam pengembangan dasar lainnya atau didalam kegiatan inti itu } \\
\text { masih sangat sedikit, atau barangkali jarang sekali. }\end{array}$} \\
\hline
\end{tabular}

Rekapitulasi hasil jawaban responden tentang pengembangan nilai-nilai agama dan moral melalui kegiatan khusus adalah sebagai berikut:

$$
\begin{aligned}
& \text { Rata-rata skor }=\frac{\text { total skor }}{\text { jumlah } \text { item }} \\
& \begin{aligned}
\text { Rata-rata skor } & =\frac{178}{10} \\
& =17.8
\end{aligned}
\end{aligned}
$$
berikut:

Selanjutnya ditentukan dalam bentuk presentasi dengan penghitungan sebagai

$$
\begin{aligned}
& \text { Presentasi skor }=\frac{\text { skor rata-rata }}{\text { skor ideal }} \times 100 \% \\
& \begin{aligned}
\text { Presentasi skor } & =\frac{860}{10} \\
& =86 \%
\end{aligned}
\end{aligned}
$$


Dari perhitungan diperoleh presentasi skor nilai $86 \%$, sehingga apabila dimasukan kedalam kategori presentase menurut Arikunto (1998:246), yaitu:

Tabel 8

Kategori Presentase

\begin{tabular}{|l|l|}
\hline Baik & $76 \%-100 \%$ \\
\hline Cukup & $56 \%-75 \%$ \\
\hline Kurang Baik & $40 \%-55 \%$ \\
\hline Tidak Baik & Kurang dari $40 \%$ \\
\hline
\end{tabular}

Maka strategi pengembangan nilai-nilai agama dan moral melalui kegiatan khususs di Taman Kanak-kanak di Jawa Barat memiliki kategori baik.

\section{KESIMPULAN DAN SARAN}

Berdasarkan hasil penelitian dapat dikemukakan kesimpulan sebagai berikut.

1. Implementasi strategi pengembangan nilai-nilai agama dan moral melalui kegiatan rutinitas dilakukan oleh hampir seluruh guru TK di Jawa Barat, sejumlah 90,25 \% guru mengetahui, memahami dan mengimplementasikannya pada pelaksanaan kegiatan rutiniitas, dan dikategorikan baik.. Adapun bentuk kegiatannya yaitu: memberi salam, mengucapkan doa, menunjukan sikap berdoa, pembiasaan mengucapkan doa masuk kelas, doa sebelum belajar, doa sebelum makan dan sesudah makan,dan doa mau pulang. Kegiatan rutinitas ini saat sekarang ini sudah menjadi kegiatan pembiasaan dan konsisten dengan aktivitas belajar anak.

2. Implementasi strategi pengembangan nilai-nilai agama dan moral melalui kegiatan terintegrasi sejumlah 48,3\% guru di Jawa Barat, mengimplementasikan pada kegiatan terintegrasi melalui kegiatan inti sehingga dikategorikan kurang baik. Selebihnya guru tidak mengetahui, tidak smemahami dan tidak melaksanakannya, karena (1) guru tidak mengetahui dan tidak memahaminya dengan strategi pengembangan nilai-nilai agam dan moral melalui kegiatan terintegrasi, (2) guru kesulitan didalam menyisipkan nilai-nilai agama dan moral pada kegiatan inti, (3) sikap stereotip guru yang mengikuti kebiasaan tentang implementasi strategi pengembangan nilai-nilai agama dan moral di Taman Kanak-kanak yang banyak dilakukan dikegiatan rutinitas atau pembiasaan, dan terakhir (4) labelisasi pengembangan nilai-nilai agama dan moral merupakan pengembangan pembiasaan yang dilakukan pada kegiatan awal. Adapun pada kegiatan inti seringkali diisi oleh kegiatan pengembangan kemampuan dasar (kognitif, bahasa, fisik-motorik) dengan terus berulang-ulang.

3. Implementasi strategi pengembangann nilai-nilai agama dan moral melalui kegiatan khusus, guru telah memahami dan melaksanakan kegiatan khusus sejumlah 86\%, sehingga dikategorikan baik. Sejumlah guru tersebut mengembangkan kegiatan khusus berupa mengahafal surat-surat pendek, menghafal doa sehari-hari, membaca iqro, menulis huruf hijaiyah, praktek wudlu, praktek sholat dan manasik haji, praktek sedekah, dan berkunjung 
ketempat ibadah. Pelaksanaan kegiatan umumnya dilaksanakan satu hari khusus dalam satu minggu yakni di hari jumat.

Berdasarkan hasil penelitian dapat dikemukakan saran-saran sebagai berikut.

1. Penelitian ini diharapkan bisa memberikan masukan bagi pihak terkait terutama para praktisi Pendidikan Anak Usia Dini agar bisa menjadi masukan didalam pengembangan nilai-nilai agama dan moral di sekolah, dan kepada para pembuat kebijakan dalam penyusunan kurikulum PGTK/RA agar pengembangan nilai-nilai Agama dan Moral, indikator pengembangan dapat dirinci secara jelas dalam pembelajaran.

2. Mengembangkan program khusus bagi guru, yaitu penekanan agar pengembangan kemampuan dasar di TK haruslah dikembangkan secara seimbang baik dikegiatan awal, inti, dan akhir. Sehingga bentuk kegiatan terintegrasi pengembangan nilai-nilai agama dan moral bisa terlaksana dengan baik, antara lain melalui pelatihan-pelatihan dan seminar-seminar.

3. Kedepannya diharapkan sebagai tindak lanjut dari Road Map penelitian ini dikembangkan model pembelajaran terintegrasi pengembangan nilai-nilai agama dan moral di TK.

\section{DAFTAR PUSTAKA}

Agus, Abu H. (2011) Penanaman nilai-nilai agama islam pada anak usia dini melalui metode bercerita di Taman kanak-kanak. Tesis. UIN Sunan Kalijaga.Yogyakarta

Aisyah, S dkk. (2007) Perkembangan dan Konsep Dasar Pengembangan Anak Usia Dini. Jakarta: Universitas Terbuka.

Al Abrasyi,A.Mohd.(1974). Dasar-dasar pokok Pendidikan Islam, Bulan Bintang, Jakarta

Arikunto, Suharsimi. 1998. Prosedur Penelitian Suatu Pendekatan (Edisi Revisi). Jakarta: PT Rineka Cipta.

Ati, B. (2009): media pengajaran di taman kanak-kanak [online] http://bundaati.blogspot.com/2009/07/ - - media-pengajaran-di taman-kanak kanak. html. diakses tanggal 27 Nopember 2013

Daeng, D, P. (1996). Metode Mengajar Ditaman Kanak-Kanak, Depdikbud, Jakarta Depdiknas.(2002). Konsep Kurikulum Reference Program Diploma II PGTK. Jakarta (1995). Petunjuk Kegiatan Penilaian di Taman Kanak-Kanak. Jakarta

Djakhiri, A.,K, at. al. (1996). Dasar-Dasar Konsep Pendidikan Moral, Depdikbud, Jakarta Dixon \& Collin. (1991). Integrated Learning Planned Curriculum Units. Australia, Bookshit Pub.

Hidayat, H .(2003). Aktivitas Mengajar TK. Kanisius. Bandung Hidayat, O. S. (2004). Assesmen Evaluasi Kegiatan TK. MMA PGTKI.Bekasi

Terbuka. Jakarta

Kartono Kartini. (1985). Mengenal Dunia Kanak-kanak.Rajawali. Jakarta

Moeslichatun. (1999). Metode Pengajaran di TK. Depdikbud. Jakarta

Moleong, Lexy J. (2011). Metodologi Penelitian Kualitatif. Remaja Rosda Karya. Bandung

Nugraha, A. (2000). Tumbuh dan Belajar Anak Usia Dini. KKB Bakat. Bogor 
Permendiknas No. 58 th. 2009.Standar Pendidikan Anak Usia Dini. Direktorat PAUD. Dirjen Pendidikan Formal dan Informal Kemendiknas. 2010

Rohendi, E. (2012). Mengembangkan Sikap dan Perilaku Anak Usia Dini melalui Pendidikan Berbasis Karakter.Cakrawala Dini. Jurnal Pendidikan Anak Usia Dini, Vol. 3, No. 1 Mei 2012, hlm 1-6

Rohendi, E. (2012). Pendekatan dan Metode Pengembangan Moral dan Nilai-nilai Agama pada Anak Usia Dini. Dalam: Yunus Abidin (Penyunting), Dimensidimensi Pembelajaran pada Anak Usia Dini, Prosiding Seminar Internasional Ke-2 Fostering Young Learners Potentials, Bandung, Rizqi Press, hlm 33-40

Supriyati, Y. (2004). Penilaian Mahasiswa dalam Melaksanakan PPL Bernuansa KBM. Jakarta

Wantah, Maria J. (2005) Pengembangan Disiplin dan Pembentukan Moral pada Anak Usia Dini. Jakarta: Direktorat Pembinaan Pendidikan Tenaga Kependidikan dan Ketenagaan Perguruan Tinggi. 